\title{
MONITORING OF LAND USE AND LAND ABANDONMENT AT THE MUNICIPAL LEVEL: EXAMPLE OF SAMARA REGION
}

\author{
Darya Vasilieva ${ }^{1}$, Cand.Sc., docent; Velta Parsova ${ }^{2}$, Dr.oec., professor; \\ Alexsandr Vlasov ${ }^{3}$, Cand.Sc., professor and Vladimir Tarbaev ${ }^{4}$, Cand.Sc., docent \\ ${ }^{1,2}$ Samara State University of Economics, ${ }^{2}$ Latvia University of Life Sciences and Technologies, ${ }^{4}$ Saratov State \\ Vavilov Agrarian University
}

\begin{abstract}
The article discusses modern legal regulation of land monitoring and necessary changes in appropriate legislation. Land monitoring is divided into monitoring of land use and monitoring of land quality. The problem of land abandonment or non-use of land resources on the example of Samara region, where more than $75 \%$ of territory is agricultural land has been studied. Inverse relationship between remoteness of local municipality from centre of the Samara-Togliatti agglomeration and area of unfarmed agricultural land has been analysed. Since the start of land reform, large areas of abandoned land have appeared in Samara region. The information on unfarmed agricultural land on municipal level of Samara region has been presented and the changes in their quality conditions are characterized. At federal level the program for prevention and elimination of land abandonment has been developed and implemented, the results of this program have been analysed.

However, there are significant problems in monitoring of land conditions. It is proved that absence of single authority for land management on national level and fragmentation of this function across different federal ministries leads to uncoordinated actions and lack of reliable information about land quality. As result, land quality continues to deteriorate, degradation processes are going on. At municipal level there are no possibilities and necessary investigation materials for land management and monitoring. The following measures are proposed as main recommendations for solving land use and land abandonment problems: creation of single authority for land stock management, implementation of comprehensive inventory of land on municipal level, improvement of cadastral valuation system according updated materials and technologies, as well as certification of agricultural land for soil quality and properties.

The purpose of the research was the study of results of land monitoring in Samara region for analysis of dynamics of land stock and identification of main reasons for formation of unused (abandoned) agricultural land in the region. It is proved that land stock of Samara region mainly consists of agricultural lands, and most part of them $(60 \%)$ are owned by citizens. Significant problem of land use is the availability of unused arable land, which is $8 \%$ on average in the region, but in local municipalities it ranges from $0 \%$ to $29 \%$. The highest proportion of unused arable land is located in areas closer to Samara-Togliatti agglomeration, where most of the land has been privatised by individuals for conversion to other land categories and further resale, as well as problems with uncontrolled urbanization there have been observed.
\end{abstract}

Key words: agricultural land, land abandonment, land monitoring, land stock, soil

JEL code: Q15; Q24

\section{Introduction}

The state of agro landscapes, which are agricultural production basis, largely determines the economic development of the country. Agro landscapes exist in human-defined regimes, so their condition depends on the quality of management to maintain the set of parameters. The equilibrium state of agro landscapes should be supported by systems of agronomic, reclamation and ecological measures. In case of non-observance of farming technologies, the balance of substance and energy is disturbed and soil fertility is degraded, productivity of agro landscapes is reduced (Trofimova, L. S.; Trofimov, I. A.; Yakovleva, E. P., 2018). To assess the activity of degradation processes, the quality of land and its use, state monitoring of land is carried out.

The article studies land monitoring system in Russian Federation. By example of one of the regions of the country the indicators of land stock state in different municipalities and the changes that have taken place within 30 years since the land reform beginning have been studied. Due to lack of single land management authority in Russia and fragmentation of this function by different ministries, 
reliable information on the state of land cannot be obtained. As a result, the state of land continues to deteriorate, as there are processes of degradation and there are no measures to prevent and eliminate them.

The hypothesis of the study is - the basis of current problems of land use in the studied region is the lack of single land management authority and fragmentation of supervision function between different agencies.

The purpose of the study is to investigate the results of land monitoring in Samara region in order to analyse the dynamics of land stock and identify main reasons for formation of unused agricultural land.

The objectives of research are - organization of land monitoring system in the Russian Federation and its federal regions, dynamics of the land categories of Samara region land stock in period 2007 - 2018, land ownership forms, distribution of unused land in municipal regions and reasons for increase of area of unused agricultural land closer to urban agglomerations.

The method of analysis of scientific literature, annual statistical data reports, tabular and graphical methods conducting the investigation were used.

\section{Research results and discussion}

State land monitoring is an organized system for monitoring the condition, qualitative and quantitative characteristics, use of land, and changes in soil fertility, as well as assessment and forecasting of changes. Depending on the purpose of monitoring, it is divided into monitoring of land use and monitoring of land conditions. Monitoring of use is carried out to track the use of land plots for their intended purpose. State monitoring of land belongs to ecological monitoring and is carried out (except for agricultural land) by Federal Service for State Registration, Cadastre and Cartography (Rosreestr) with application of certain criteria. Such criteria in monitoring of land use include: total area of land of certain category; area of land with certain type of intended use; area of land not used for their intended purpose, not used or with violations of land legislation identified; distribution of land according form of ownership; area of developed land; area of forest stock registered into the state real estate cadastre etc. (State (national) report..., 2018). Land monitoring data are periodically published in the form of national report on the state and use of land in the Russian Federation, as well as regional reports for each subject of the Russian Federation (Report on the state and use of lands in Samara region, 2019). Monitoring of agricultural land condition and use is the responsibility of Ministry of Agriculture of the Russian Federation, and results of this monitoring are also periodically published in the open press (Report on the state and use of land in Samara region, 2019; Report on the state and use of agricultural land in Russian Federation, 2018).

Large areas of abandoned land need to be involved in economic activities or used to increase forest cover, which is done in many countries. Promoting afforestation is often mentioned as strategy to combat global climate changes (Bala, G. and others, 2007; Noszczyk, T. 2018; Clavero, M., Villero, D., Brotons, L., 2011; Gibbard, S. and others, 2005).

The territory of Samara Region is located in the south-east of the East-European Plain in the Middle Volga Region on the border of steppe and forest-steppe natural zones. Black soils prevail in the soil cover: black soils leached (21.8\%), typical (24.9\%), ordinary $(19.1 \%)$ and southern (30.6\%). Other soils have small areas: dark grey forest soils $(1.2 \%)$, black soils (1.1\%), floodplain meadow soils $(0.6 \%)$, saline soils $(0.4 \%)$, dark chestnut soils $(0.04 \%)$ etc. (Voronin, V. V., Vlasov, A. G., Vasilieva, D. I., 2013). 
Most of the region's territory is formed by agricultural landscapes. The study of dynamics of main indicators of agricultural land state and soil fertility shows that Samara region is characterized by decrease in the quality parameters of agro landscapes. The last soil survey in Samara Region was conducted in 2003-2004. It showed that more than half of total area of agricultural land $(51 \%)$ is erosively dangerous and most of it is eroded to different degrees. An analysis of materials from the "Samarskaya" agrochemical service station showed that, since 1992, the balance of nutrients in arable soils in Samara oblast has become negative (Obushchenko, S. V., 2014). Extraction of nutrients from crop has become much more prevalent than the return of nutrients to the soil (Gnidenko V. V., Obushchenko, S. V., 2013).

\section{Organization and results of monitoring of land stock of Samara region}

The agricultural land category prevails on the territory of the region, which occupies $75.9 \%$ of the territory, while the share of other categories is as follows: forest stock $-10.3 \%$; land of settlements $-6.7 \%$; water stock $-3.1 \%$; specially protected territories $-2.6 \%$; industry, transport and other special purpose $-1.3 \%$; land reserve $-0.01 \%$ (Report on the state and use of lands in Samara region, 2019).

Department of Federal Service for State Registration, Cadastre and Cartography of Samara Region (Rosreestr) is responsible for state monitoring of land of all categories, except category of agricultural land in the Samara Region. Monitoring of agricultural land is carried out by Ministry of Agriculture and Food of Samara Region. The results of annual monitoring of land in Samara region according land categories conducted by Rosreestr are given in the table 1 .

Table 1

Dynamics of Samara Region land stock*

\begin{tabular}{|c|c|c|c|c|c|c|c|}
\hline \multirow{2}{*}{ No } & \multirow{2}{*}{ Land category } & \multicolumn{6}{|c|}{ Area, thousand ha } \\
\hline & & 2007 & 2010 & 2013 & 2015 & 2017 & 2018 \\
\hline 1. & Agricultural land & 4112.5 & 4089.4 & 4070.1 & 4067.4 & 4067.2 & 4067.2 \\
\hline \multirow{3}{*}{2.} & Land of settlements, including & 344.4 & 356.2 & 359.3 & 359.6 & 359.8 & 359.8 \\
\hline & - urban settlements & 168.5 & 170.8 & 170.8 & 170.8 & 170.8 & 170.8 \\
\hline & - rural communities & 175.9 & 185.4 & 188.5 & 188.8 & 189.0 & 189.0 \\
\hline 3. & $\begin{array}{l}\text { Land of industry, transport and other special } \\
\text { purposes }\end{array}$ & 69.6 & 70.0 & 71.0 & 71.5 & 71.5 & 71.5 \\
\hline 4. & Specially protected areas & 135.3 & 138.8 & 138.8 & 138.8 & 138.8 & 138.8 \\
\hline 5. & Forest land & 527.0 & 534.4 & 549.6 & 551.5 & 551.5 & 551.5 \\
\hline 6. & Land under water & 167.4 & 167.4 & 167.4 & 167.4 & 167.4 & 167.4 \\
\hline 7. & Reserve land & 0.3 & 0.3 & 0.3 & 0.3 & 0.3 & 0.3 \\
\hline \multicolumn{2}{|r|}{$\begin{array}{l}\text { Total within administrative boundaries of } \\
\text { Samara Region }\end{array}$} & \multicolumn{6}{|c|}{5356.5} \\
\hline
\end{tabular}

Source: compiled by authors according to the reports on state and use of land in the Samara region 2007-2018 (Report on the state and use of lands in Samara region, 2019)

Analysis of presented data allows authors to make the conclusion that there is gradual decrease of land of agricultural category, 45.3 thousand hectares decreased from 2007 to 2018. At the same time, the area of residential lands category increased by 15.4 thousand ha, industrial and other special purpose land - by 1.9 thousand ha, land of specially protected territories and objects - by 3.5 thousand ha, and land of forest stock - by 24.5 thousand ha. The area of land under water and reserve land has remained unchanged since 2007. Thus, the main losses of agricultural land are related to urbanization mainly within boundaries of Samara-Togliatti agglomeration, as well as to settling of the long-used arable land and transfer of such land to forest stock category 
(Kondolskaya, A., Vasilieva, D., Parsova, V., Antropov, D., 2019). The problem of preserving agricultural and forest land for sustainable development of society is very acute in many countries (Kurowska, K., Kryszk, H., 2016; Louwagie G., Gay S. H., Sammeth F., Ratinger T., 2011; Zuazo, V. H. D. and others, 2011).

\section{Land use monitoring in Samara region}

The results of Samara region land use monitoring as of 01.01 .2019 are presented in the table 2 . It has been already mentioned that in Samara region agricultural land prevails (over $75 \%$ ) in the general structure of the land fund, therefore a lot of attention should be paid to monitoring of this land.

Presented data analysis shows that privatized land in agricultural category in Samara region to the greatest extent (more than $68 \%$ ) is owned by private and legal persons, while the rest land is ownership of state and municipalities. Therefore, an important issue is an improvement of complex of administrative and control measures for monitoring and management of agricultural land. Great attention should be paid to monitoring of land use according its intended purpose, especially those which are owned by agricultural enterprises. It is necessary to continue taking measures to involve unused lands in circulation.

Table 2

\section{Breakdown of land stock by types of ownership in Samara region*}

\begin{tabular}{|l|l|l|l|l|l|l|l|l|}
\hline No & \multicolumn{1}{|l|}{$\begin{array}{l}\text { Land } \\
\text { category }\end{array}$} & $\begin{array}{l}\text { Total } \\
\text { area }\end{array}$ & $\begin{array}{l}\text { Owned } \\
\text { by } \\
\text { citizens }\end{array}$ & $\begin{array}{l}\text { Owned } \\
\text { by legal } \\
\text { entities. }\end{array}$ & $\begin{array}{l}\text { State and } \\
\text { municipal } \\
\text { property }\end{array}$ & $\begin{array}{l}|c| \\
\text { owned by } \\
\text { national } \\
\text { level } \\
\text { authority }\end{array}$ & $\begin{array}{l}\text { owned by } \\
\text { regional } \\
\text { level } \\
\text { authority }\end{array}$ & $\begin{array}{l}\text { municipal } \\
\text { property }\end{array}$ \\
\hline 1. & $\begin{array}{l}\text { Agricultural } \\
\text { land }\end{array}$ & 4067.2 & 2459.6 & 296.7 & 1310.9 & 113.2 & 0 & 0 \\
\hline 2. & $\begin{array}{l}\text { Lands of } \\
\text { settlements }\end{array}$ & 359.8 & 70.3 & 20.1 & 269.4 & 23.6 & 7.3 & 9.1 \\
\hline & $\begin{array}{l}\text { Lands of } \\
\text { industry, } \\
\text { transport } \\
\text { and other } \\
\text { special } \\
\text { purposes }\end{array}$ & 71.5 & 0.7 & 1.6 & 52.6 & 40.7 & 11.3 & 0.6 \\
\hline 4. & $\begin{array}{l}\text { Specially } \\
\text { protected } \\
\text { areas }\end{array}$ & 138.8 & 0 & 0 & 138.8 & 105,7 & 0 & 0 \\
\hline 5. & Forest land & 551.5 & 0 & 0 & 551.5 & 326.1 & & 0 \\
\hline 6. & Water stock & 167.4 & 0 & 0 & 167.4 & 0.8 & 0 & 0 \\
\hline 7. & Reserve land & 0.3 & 0 & 0 & 0.3 & 0 & 0 & 0 \\
\hline
\end{tabular}

Source: compiled by authors according to the data of Reports on the condition and use of lands of Samara region 2007-2018 (Report on the state and use of lands in Samara region, 2019)

The results of land state monitoring of Samara region on 01.01.2019 are shown in the figure 1 . 


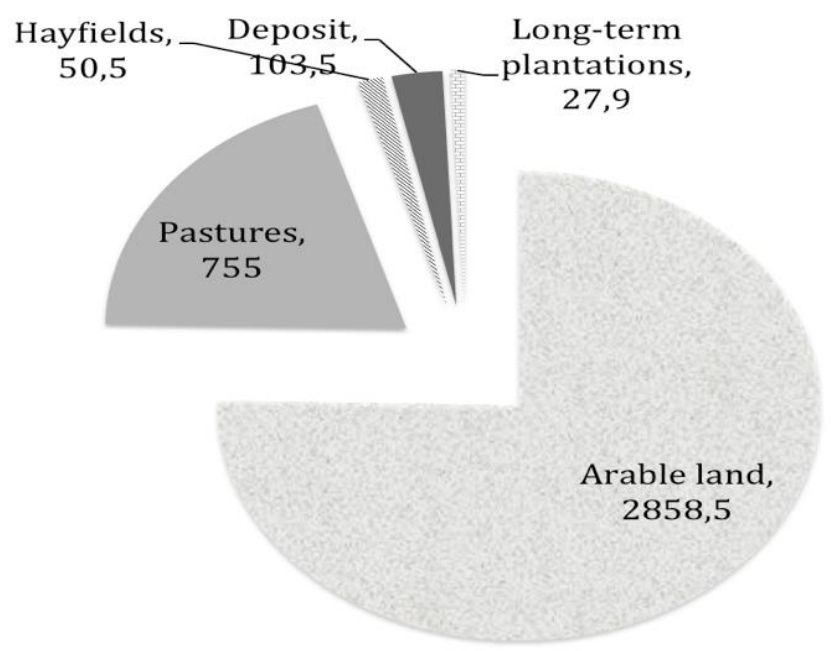

Fig. 1. Breakdown of agricultural land in Samara region, thousand ha

Analysing breakdown of agricultural land, it can be seen that arable land prevails, occupying $70 \%$ of total area of agricultural land. The share of pastures is $18 \%$ of in this category, the share of fallows $-2.5 \%$, meadows - $1.2 \%$, and perennial plantations $-0.7 \%$. The results of monitoring of agricultural land are presented in the table 3.

Table 3

Samara Region land fund dynamics*

\begin{tabular}{|l|l|c|c|c|}
\hline \multirow{2}{*}{ No } & \multicolumn{1}{|c|}{ Type of land use } & \multicolumn{3}{c|}{ Area, thousand ha } \\
\cline { 3 - 5 } & & $\mathbf{2 0 1 6}$ & $\mathbf{2 0 1 9}$ & $\begin{array}{c}\text { Changes } \\
\mathbf{2 0 1 6 / 2 0 1 9}\end{array}$ \\
\hline 1. & Arable land & 2859.9 & 2858.5 & -1.4 \\
\hline 2. & Perennial plantations & 27.8 & 27.9 & +0.1 \\
\hline 3. & Meadows and pastures & 805.5 & 805.5 & 0 \\
\hline 4. & Bushes & 90.1 & 90.1 & 0 \\
\hline 5. & Forest land & 21.3 & 21.3 & 0 \\
\hline 6. & Land under construction & 16.2 & 16.2 & 0 \\
\hline 7. & Land under roads, communications, streets, squares & 41.7 & 41.7 & 0 \\
\hline 8. & Land under water & 36.0 & 36.0 & 0 \\
\hline 9. & Swamps & 34.6 & 34.6 & 0 \\
\hline 10. & Disturbed land & 0.5 & 0.5 & 0 \\
\hline 11. & Deposits & 103.5 & 103.5 & 0 \\
\hline 12. & Other & 26.5 & 26.5 & 0 \\
\hline
\end{tabular}

Source: compiled by authors according to the Reports on the state and use of land in the Samara region 2007-2018 (Report on the state and use of lands in Samara region, 2019)

There were no changes in land areas in 2019 compared to the previous years. Analysis of the dynamics for last three years showed decrease of arable land area by 1.4 thousand hectares and increase of perennial plantings area by 0.1 thousand hectares.

In order to monitor and assess the conditions and efficiency of agricultural land use in municipal districts of Samara region, the Commission at Ministry of Agriculture and Food of Samara region has been established. The tasks of this commission are to inspect the objects in accordance with the criteria of efficiency assessment, summarize the assessment and make rating of municipal areas of Samara region. For evaluation, the following criteria have been developed:

- share of cultivated arable land (\%);

- visually assessed condition of fallow land; 
- general management standard - visually assessed condition of crops, presence of weeds, condition of field roads;

- phytosanitary conditions of areas adjacent to production facilities of agro industrial complex;

- carrying out of measures aimed at combating quarantine objects - weeds;

- increase or decrease of areas infested with quarantine weeds;

- improvement of agricultural production facilities;

- conditions of protective forest belts;

- maintenance of territories adjacent to roads of local, regional and federal significance;

- conditions of areas around poles, power lines, gas pipelines etc.

Use and condition of agricultural land in Samara region is the most important factor both in ensuring food security and creating of ecological balance of territory. Information on unused agricultural land in municipal districts of Samara Region on 01.01.2019 is given in figure 2 .

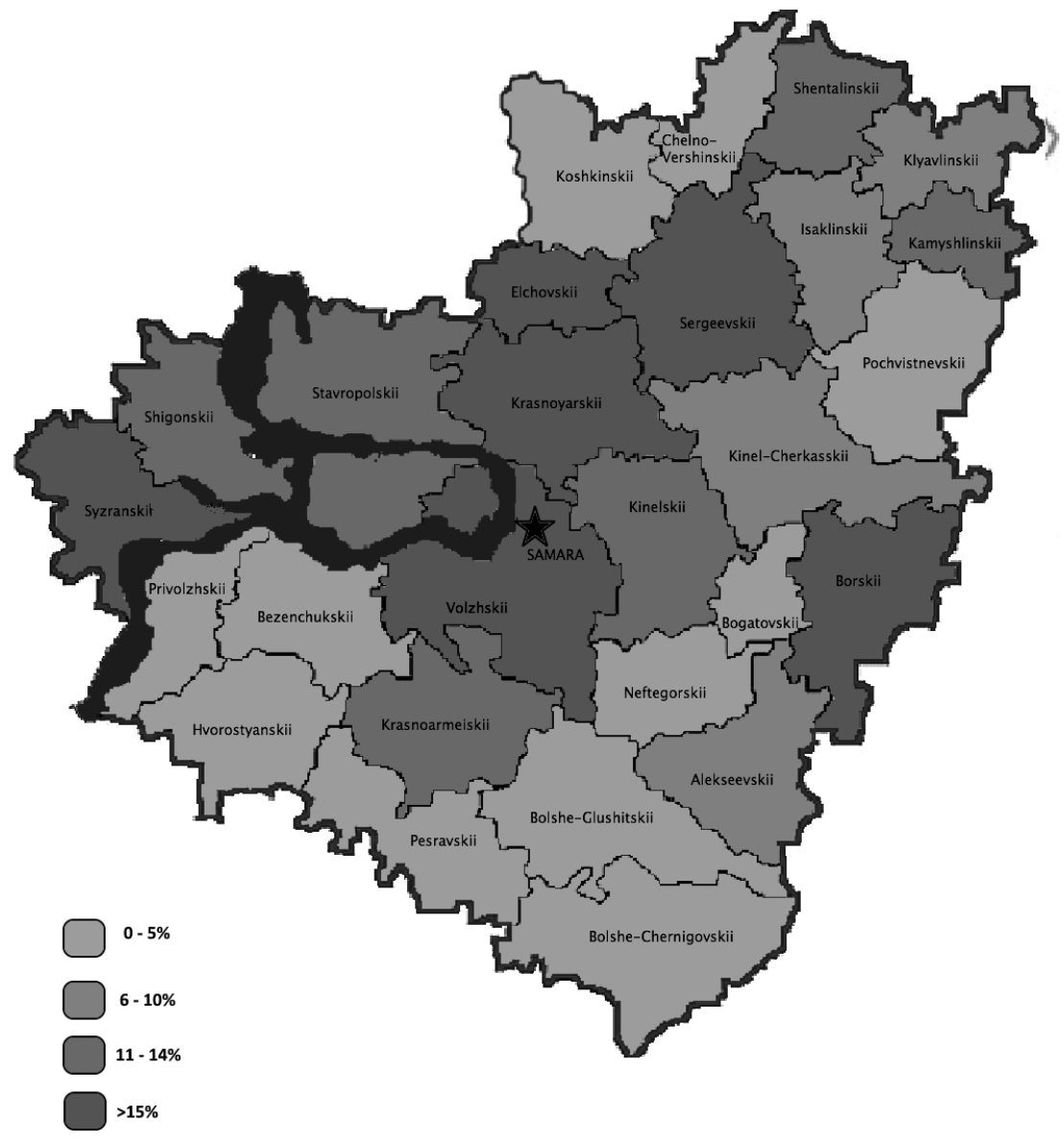

Fig. 2. Location of unused land in municipal areas of Samara region, \%

On average $8 \%$ of agricultural land is not used in the region. However, this indicator varies greatly from municipality to municipality. In some municipalities (Bogatovsky, Bolsheglushitsky, Bolshechershnigovsky, Koshkinsky, Neftegorsky, Pestravsky, Hvorostyansky and Pokhvistnevsky) this indicator is equal or close to zero. But in some municipalities it is significantly above the regional average: Elkhovsky - $29 \%$, Sergievsky - $22 \%$, Borsky - $20 \%$, Syzransky - $18 \%$, Volzhsky $18 \%$, Krasnoyarsky - $15 \%$ etc. The majority of municipalities located far from regional centre have small proportion of unused arable land. In peri-urban areas, on the contrary, this indicator is higher, as agricultural land is often purchased by individuals in order to be transferred to another category. 
It should be noted that total area of unused arable land in Samara region has decreased in recent years: in 2007 about 700 thousand ha (24\%) of arable land was not used, in 2011 this indicator was reduced to 417 thousand ha (15\%). Measures taken by the Ministry of Agriculture and Food to engage in the turnover of unused arable land have led to reduction of unused land area. Road maps have been developed for some municipal districts to organize and conduct an inventory of agricultural land in order to identify arable land that is not used for agricultural production and is not used for its intended purpose.

Monitoring of land use is an important part of the land management system. Modern problems in the field of state land management lead to violations of land laws, such as:

- unauthorized land seizure;

- occupation of valuable agricultural land and land of environmental importance;

- use of land not for its intended purpose and in contradiction with the permitted use;

- consumer use of land, which leads to depletion of soil fertility or loss of the soil layer etc.

\section{Conclusions, proposals, recommendations}

Improving the land management system, it is required to address land management problems. Unreasonable and thoughtless change of legislation in the sphere of land management, simplification and rejection of land management activities can lead to irreparable damage.

Process of further improvement of land management monitoring is currently under way. Plan of measures to improve legal regulation of land relations has been approved by Government of the Russian Federation in 2018. Adoption of number of federal laws under this Plan will facilitate solving of problems in use of land resources and increase the responsibility of legal persons and individuals working on land. There should be implemented protection of agricultural land and reduction of withdrawal of land from agricultural turnover. In author's opinion most important directions for improving the land legislation of the Russian Federation are as follows:

- establishment of criteria for attributing land to especially valuable agricultural land and its allocation to separate territorial zone;

- determination of the procedure for changing of types of permitted use of land;

- establishment of restrictions for changing of types of permitted use of especially valuable agricultural land, as well as ban of open-cast mining of common minerals on agricultural land;

- improvement of the inventory system of the land, especially of agricultural land;

- carrying out of passporting of agricultural land in order to obtain an information on soil conditions and properties, etc.

\section{Bibliography}

1. Bala, G., Caldeira, K., Wickett, M., Phillips, T.J., Lobell, D.B., Delire, C., Mirin, A. (2007). Combined Climate and Carbon-cycle Effects of Large-scale Deforestation. Proceedings of the National Academy of Sciences, 104(16). pp. 6550-6555.

2. Clavero, M., Villero, D., Brotons, L. (2011). Climate Change or Land Use Dynamics: Do We Know What Climate Change Indicators Indicate?. PLoS One, 6(4), e18581. https://doi.org/10.1371/journal.pone.0018581

3. Gibbard, S., Caldeira, K., Bala, G., Phillips, T.J., Wickett, M., (2005). Climate Effects of Global Land Cover Change. Geophysical Research Letters, 32(23).

4. Gnidenko V.V., Obushchenko S.V. (2013). Dynamics of Soil Fertility Changes in Samara Region. Proceedings of Modern Natural Science. №9. pp. 148-151.Noszczyk, T. (2018). Land Use Change Monitoring as a Task of Local Government Administration in Poland. Journal of Ecological Engineering. 19. 170-176. $10.12911 / 22998993 / 79409$.

5. Kondolskaya, A., Vasilieva, D., Parsova, V., Antropov, D. (2019) Problems of Conservation and Use of Agricultural Land in Urban Agglomerations. 18th International Scientific Conference Engineering for rural Development Proceedings, Volume. pp. 774-779. 
6. Kurowska, K., Kryszk, H. (2016). Influence of Agricultural and Forest Land Protection on Development of Investment and Construction Process in Poland. International Multidisciplinary Scientific GeoConference: SGEM: Surveying Geology \& Mining Ecology Management, 2, pp. 485-492.

7. Louwagie G., Gay S.H., Sammeth F., Ratinger T. (2011). The Potential of European Union Policies to Address Soil Degradation in Agriculture. Land Degradation \& Development, 25, pp. 5 - 17.

8. Obushchenko, S.V. (2014). Dynamics of the Main Indices of the Soil Fertility in the Samara Region for 50 years (in Russian) // Agrarian and industrial complex science and technology achievements. №1. pp. 14-16.

9. Trofimova, L.S.; Trofimov, I.A.; Yakovleva, E.P. (2018) Agrolandscape Assessment, Challenges of their Monitoring and Management in Russia (in Russian). New methods and results of the landscape research in Europe, Central Asia and Siberia. Monograph. In 5 volumes (in Russian). New methods and results of investigations of landscapes in Europe, Central Asia and Siberia. Under edition of V.G. Sychev, L.Muller. Moscow: Publishing house of D.N. Pryanishnikov All-Russian Research Institute of Agrochemistry. pp. 114118.

10. State (national) report on the state and use of land in the Russian Federation in 2017. - Moscow: Rosreestr, 2018. p. 197.

11. Report on the State and Use of Agricultural Lands in the Russian Federation in 2016. (2018). Moscow: FSBNU Rosinformagroteh. p. 240.

12. Report on the state and use of lands in Samara region in 2018. (2019) Federal Service for State Registration, Cadastre and Cartography Department for Samara Region. Samara.

13. Vlasov, A.G. Vasilieva, D.I. (2018) Dynamics of the Samara Region Land Fund Condition as a Result of the Land Reform // Innovative approaches to the sustainable development of the social and ecological economic systems. - Proceedings of the fifth International conference. Institute of Volga Basin Ecology of the Russian Academy of Sciences; SSEU. pp. 28-33.

14. Voronin, V.V., Vlasov, A.G., Vasilieva, D.I. (2013) Structure and Quality Estimation of the Samara Region Lands (in Russian) // Problems of regional ecology. №4. pp. 109-116.

15.Zuazo, V.H.D., Pleguezuelo, C.R.R., Flanagan, D., Tejero, I.G., Fernandez, J.L.M. (2011). Sustainable Land Use and Agricultural Soil. In Alternative Farming Systems, Biotechnology, Drought Stress and Ecological Fertilisation. Springer, Dordrecht. pp. 107-192. 